\title{
Peran Trichoderma harzianum sebagai Penghasil Zat Pengatur Tumbuh terhadap Pertumbuhan dan Produktivitas Varietas Cabai (Capsicum annuum L.)
}

\section{The Role of Trichoderma harzianum as a Producer of Growth Regulating Substances on the Growth and Productivity of Chili Varieties (Capsicum annuum L.)}

\author{
Eka Fitria ${ }^{1}$, Elly Kesumawaty ${ }^{2}$, Bakhtiar Basyah ${ }^{2}$, dan Asis ${ }^{\text {* }}$
}

${ }^{1}$ Balai Pengkajian Teknologi Pertanian Aceh

J1. Panglima Nyak Makam No. 27 Lampineung-Banda Aceh, Aceh 23125, Indonesia

${ }^{2}$ Program Studi Agroteknologi Universitas Syiah Kuala. Banda Aceh 23111, Indonesia

Diterima 27 Januari 2021/Disetujui 26 April 2021

\begin{abstract}
Chili is Indonesia's main commodity in the field of horticulture with high economic value and is very much needed by the community as a seasoning for cooking. Each chili variety has different adaptability to the environment so it is very important to adapt the growing environment for plant growth. The application of soil microorganisms is carried out as a supporting element for the growth and development of chili plants. This study aimed to determine the effect of variety introduction and application of $\underline{T}$. harzianum pellet dosage on the growth and productivity of chilies. This research was conducted from February to July 2017 in Lamreung village, Krueng Barona Jaya District, Aceh Besar District using a randomized complete block design (RCBD) with 2 factors, namely varieties (V) consisting of Lado (V1), Kencana (V2), Bemeri (V3) and Kopay (V4), and the dosage of $\underline{T}$. harziaunum pellets consisting of $0 \mathrm{~g}$ per plant (T0), $10 \mathrm{~g}$ per plant (T1), $15 \mathrm{~g}$ per plant (T2) and $20 \mathrm{~g}$ per plant (T4) which were replicated 3 times. Treatment of varieties and pellet doses of $\underline{T}$. harzianum did not affect plant productivity, but the variety factor had a significant effect on the average plant height and canopy width, with Lado variety showing the best results. The treatment dose of $\underline{T}$. harzianum had a highly significant effect on the average root length, with the best results obtained from the application of $\underline{T}$. harzianum $20 \mathrm{~g}$ per plant.
\end{abstract}

Keywords: growth stimulants, pellet dose, plant cultivation, soil microorganism, superior seeds

\section{ABSTRAK}

Cabai merupakan komoditas unggulan Indonesia dibidang hortikultura dengan nilai ekonomi tinggi dan sangat dibutuhkan masyarakat sebagai bumbu penyedap masakan. Setiap varietas cabai memiliki daya adaptasi yang berbeda terhadap lingkungan sehingga sangat penting untuk menyesuaian lingkungan tumbuh untuk mengoptimalkan pertumbuhan tanaman. Aplikasi mikroorganisme tanah dilakukan sebagai unsur pendukung peningkatan pertumbuhan dan perkembangan tanaman cabai. Penelitian ini bertujuan untuk mengetahui pengaruh introduksi varietas dan aplikasi dosis pellet $\underline{T}$. harzianum terhadap pertumbuhan dan produktivitas cabai. Penelitian ini dilaksanakan pada bulan Februari-Juli 2017 di desa Lamreung, Kecamatan Krueng Barona Jaya, Kabupaten Aceh Besar, menggunakan rancangan kelompok lengkap teracak (RKLT) dengan 2 faktor yaitu varietas (V) terdiri atas varietas Lado (V1), Kencana (V2), Bemeri (V3) dan Kopay (V4) dan dosis pellet $\underline{T}$. harziaunum terdiri atas $0 \mathrm{~g}$ per tanaman (T0), $10 \mathrm{~g}$ per tanaman (T1), $15 \mathrm{~g}$ per tanaman (T2) dan $20 \mathrm{~g}$ per tanaman (T4) yang diulang sebanyak 3 kali. Perlakuan varietas dan dosis pellet $\underline{T}$. harzianum tidak berpengaruh terhadap produktivitas tanaman, tetapi faktor varietas memiliki pengaruh signifikan terhadap rata-rata tinggi tanaman dan

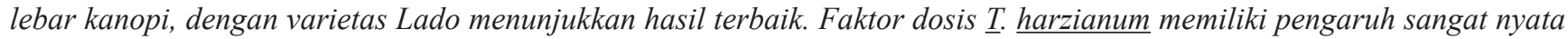

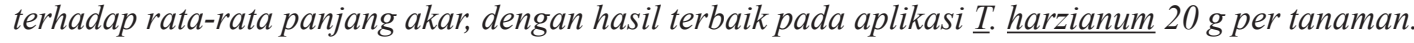

Kata kunci: benih unggul, budidaya tanaman, dosis pellet, mikroorganisme tanah, perangsang tumbuh

\footnotetext{
* Penulis untuk korespondensi. e-mail: asissp_89@yahoo.co.id
} 


\section{PENDAHULUAN}

Cabai merupakan komoditas andalan Indonesia dibidang hortikultura yang karena memiliki nilai ekonomi tinggi dan sangat dibutuhkan masyarakat sebagai bumbu penyedap masakan, bahan baku obat-obatan dan zat pewarna alami. Pertumbuhan tanaman cabai sangat ditentukan oleh tingkat adaptasi tanaman terhadap lingkungan tumbuh sesuai dengan karekter genetik (varietas) karena setiap varietas memiliki daya pertumbuhan yang berbeda pada tempat dan waktu yang sama. Pertumbuhan dan komponen produksi tanaman merupakan hasil kuantitatif yang diperoleh dari ekspresi tanaman akibat faktor genetik dan kondisi lingkungan tumbuh tanaman (Zuhry et al., 2012). Kemampuan tanaman dalam menyesuaikan pada lingkungan tumbuh ditentukan oleh karakterisasi dan sifat masing-masing varietas yang dapat mengatasi perubahan lingkungan tumbuh. Setiap varietas memiliki adaptasi yang berbeda-beda terhadap lingkungan sehingga sangat penting untuk memperhatikan kesesuaian lingkungan tumbuh tanaman (Marliah et al., 2011).

Salah satu kondisi lingkungan yang mempengaruhi pertumbuhan tanaman cabai adalah penyakit layu fusarium yang banyak menyerang pada fase vegetatif dan generatif. Tanaman cabai memiliki sifat rentan terhadap penyakit layu fusarium sehingga aplikasi Trichoderma harzianum dapat mengendalikan layu fusarium dan meningkatkan pertumbuhan tanaman dengan peningkatan ZPT pada tanaman cabai. T. harzianum adalah salah satu jenis jamur antagonis yang umum diaplikasikan sebagai pengendali patogen tular tanah (agensia hayati), mikroorganisme pengurai (biodekomposer) bahan organik dan merangsang pertumbuhan tanaman (Hardianti et al., 2014; Hermosa et al., 2012; Hermosa et al., 2013). Selain itu, agens hayati jenis $T$. harzianum mempunyai mekanisme kerja yang lebih baik dibandingkan dengan jenis Trichoderma sp. lainnya. Menurut Sriwati et al., (2014) T. harzianum mampu bertahan hidup dan menguasai ruang tumbuh dengan baik sehingga mempunyai tingkat kompetisi yang tinggi jika berkembang biak pada lingkungan tumbuh yang sama dengan patogen. Fungsi T. harzianum pada tanaman terus bertambah seiring dengan peningkatan pengetahuan, berupa peran untuk meningkatkan pertumbuhan dan produksi tanaman karena dapat berperan aktif merangsang perkembangan sel-sel tanaman sebagai zat pengatur tumbuh (ZPT) pada tanaman.

Penelitian ini bertujuan untuk mendapatkan varietas cabai dan dosis pellet T. harzianum yang dapat meningkatkan pertumbuhan dan produktivitas cabai sehingga dapat diterapkan sebagai teknologi budidaya pada tanaman cabai.

\section{BAHAN DAN METODE}

Penelitian ini dilaksanakan pada bulan Februari-Juli 2017 di Desa Lamreung, Kecamatan Krueng Barona Jaya, Kabupaten Aceh Besar. Bahan yang digunakan adalah pellet T. harzianum $1 \mathrm{~kg}$ (Pelet Laboratorium Penyakit Tumbuhan Fakultas Pertanian, Universitas Syiah Kuala), tanah entisol, pupuk kandang, sekam, dan insektisida.
Rancangan penelitian adalah rancangan kelompok lengkap teracak (RKLT) pola faktorial yaitu faktor varietas (V) terdiri dari $\mathrm{V}_{1}=$ Lado, $\mathrm{V}_{2}=$ Kencana $\mathrm{V}_{3}=$ Bemeri, dan $\mathrm{V}_{4}=$ Kopay, sedangkan faktor dosis pellet $T$. harzianum $(\mathrm{T})$ terdiri dari $\mathrm{T}_{0}=0 \mathrm{~g}$ per tanaman (kontrol), $\mathrm{T}_{1}=10 \mathrm{~g}$ per tanaman, $\mathrm{T}_{2}=15 \mathrm{~g}$ per tanaman, $\mathrm{T}_{3}=20 \mathrm{~g}$ per tanaman, yang diulang sebanyak 3 kali sehingga terdapat 48 unit percobaan dengan jumlah sampel 5 tanaman per perlakuan.

Komposisi pellet T. harzianum adalah dedak (31.0 g), ampas tahu $(10.5 \mathrm{~g})$, molase $(15.0 \mathrm{ml})$ dan air steril $(42.0 \mathrm{ml})$ yang dibentuk secara aseptik pada laminar air flow (Zikriah, 2016). Aplikasi dilakukan pada media tumbuh cabai yang berasal dari campuran tanah top soil, pupuk kandang, dan sekam dengan perbandingan 2:1:1 dalam polibag dengan ukuran $35 \mathrm{~cm}$ x $35 \mathrm{~cm}$. Pengaplikasian T. harzianum digunakan dalam bentuk formulasi pellet yang dipadatkan sesuai dengan dosis pengujian pellet $T$. harzianum pada media tanam, bersamaan dengan penanaman bibit (bibit berumur 30 hari setelah semai) pada polibag. Pemupukan dilakukan untuk meningkatkan ketersedian nutrisi tanaman dengan pupuk NPK majemuk (16:16:16) dengan dosis 2.5 g per tanaman yang dilarutkan pada $10 \mathrm{~L}$ air $(240 \mathrm{~mL}$ per tanaman) pada umur 14 dan 56 hari setelah tanaman (HST).

Variabel yang diamati adalah tinggi tanaman (cm) umur 20, 40 dan 60 HST, jumlah cabang (cabang) umur 20, 40 dan 60 HST, lebar kanopi (cm) umur 20, 40 dan 60 HST, panjang akar (cm) umur 120 HST, bobot segar akar (g) umur 120 HST, bobot kering akar (g) umur 120 HST, bobot brangkasan basah (g) umur 120 HST, bobot brangkasan kering (g) umur 120 HST dan bobot buah per tanaman (g). Hasil pengamatan dianalisis dengan analisis ragam (ANOVA) $\alpha=5 \%$, dilanjutkan dengan duncan multiple range test (DMRT) $\alpha=5 \%$.

\section{HASIL DAN PEMBAHASAN}

\section{Tinggi Tanaman}

Hasil analisis ragam (Tabel 1) menunjukkan bahwa faktor varietas cabai berpengaruh sangat nyata terhadap tinggi tanaman umur 20, 40, dan 60 HST tetapi dosis pellet T. harzianum tidak berpengaruh terhadap tinggi tanaman. Hasil uji lanjut (Tabel 2) faktor varietas menunjukkan bahwa varietas Lado memiliki rata-rata tertinggi yang berbeda nyata dengan varietas Kencana dan Bemeri pada umur 60 HST. Hal ini menunjukkan bahwa tinggi tanaman pada masingmasing varietas cabai yang diuji sangat beragam berdasarkan sifa-sifat varietas. Pertumbuhan dan perkembangan tanaman menjadi salah satu tolak ukur ekspresi sifat genetik terhadap kondisi lingkungan tumbuh tanaman. Karakteristik setiap varietas berdasarkan masing-masing deskripsi menunjukkan bahwa varietas Lado memiliki potensi tinggi tanaman 90$100 \mathrm{~cm}$, Kencana $112.6-125.6 \mathrm{~cm}$, Bemeri $65.52-68.20 \mathrm{~cm}$, dan Kopay 120-150 cm. Hal ini menunjukkan perbedaan karakteristik genetik pada setiap varietas yang diujikan dan kemampuan varietas Lado dalam mencapai potensi tinggi tanaman lebih baik pada kondisi lingkungan tertentu dengan aplikasi T. harzianum. 
Tabel 1. Hasil analisis ragam, pengaruh faktor varietas dan dosis pellet T. harzianum terhadap variabel pertumbuhan vegetatif dan generatif tanaman cabai

\begin{tabular}{|c|c|c|c|}
\hline \multirow{2}{*}{ Variabel } & \multicolumn{3}{|c|}{ Perlakuan } \\
\hline & Varietas (V) & T. harzianum $(\mathrm{T})$ & Interaksi VxT \\
\hline \multicolumn{4}{|l|}{ Tinggi tanaman $(\mathrm{cm})$} \\
\hline 20HST & $* *$ & tn & tn \\
\hline $40 \mathrm{HST}$ & $* *$ & tn & tn \\
\hline $60 \mathrm{HST}$ & $* *$ & tn & tn \\
\hline \multicolumn{4}{|l|}{ Jumlah cabang tersier (cabang) } \\
\hline $20 \mathrm{HST}$ & tn & tn & tn \\
\hline $40 \mathrm{HST}$ & tn & tn & tn \\
\hline $60 \mathrm{HST}$ & $\operatorname{tn}$ & tn & tn \\
\hline \multicolumn{4}{|l|}{ Lebar kanopi (cm) } \\
\hline $20 \mathrm{HST}$ & $* *$ & tn & tn \\
\hline $40 \mathrm{HST}$ & $* *$ & tn & tn \\
\hline $60 \mathrm{HST}$ & $* *$ & tn & tn \\
\hline Panjang akar (cm) & $*$ & $* *$ & $\operatorname{tn}$ \\
\hline Bobot segar akar (g) & tn & tn & tn \\
\hline Bobot kering akar (g) & tn & tn & tn \\
\hline Bobot brangkasan basah (g) & $* *$ & tn & tn \\
\hline Bobot brangkasan kering $(\mathrm{g})$ & $* *$ & $*$ & tn \\
\hline Bobot buah per tanaman (g) & tn & tn & tn \\
\hline
\end{tabular}

Keterangan: $* *=$ berpengaruh nyata pada taraf $1 \% ; *$ = berpengaruh nyata pada taraf $5 \%$; th = tidak berpengaruh nyata; berdasarkan analisis ragam (ANOVA)

Tanaman dapat mencapai potensi genetik secara optimal jika kondisi lingkungan tumbuh sesuai dengan syarat-syarat tumbuh tanaman dari aspek unsur hara, air dan iklim. Indikator pertumbuhan vegetatif tanaman menjadi salah satu alat ukur untuk mengetahui proses pertumbuhan akibat pengaruh lingkungan atau manipulasi lingkungan tumbuh (perlakuan). Hasil penelitian Rohmawati et al. (2018) menunjukkan bahwa perlakuan jenis varietas hibrida Pelita menghasilkan tinggi dan jumlah daun tanaman yang lebih baik terhadap varietas lokal (Tripang) pada tanaman cabai rawit.

Tabel 2. Rata-rata tinggi tanaman varietas cabai dengan aplikasi berbagai dosis T. harzianum umur 20, 40, dan 60 HST

\begin{tabular}{|c|c|c|c|}
\hline \multirow{2}{*}{ Perlakuan } & \multicolumn{3}{|c|}{ Tinggi tanaman $(\mathrm{cm})$} \\
\hline & $20 \mathrm{HST}$ & $40 \mathrm{HST}$ & $60 \mathrm{HST}$ \\
\hline \multicolumn{4}{|l|}{ Varietas (V) } \\
\hline Lado & $43.85 \mathrm{a}$ & $78.94 a$ & $88.84 \mathrm{a}$ \\
\hline Kencana & $34.88 \mathrm{c}$ & $67.08 \mathrm{c}$ & $80.45 c$ \\
\hline Bemeri & $39.51 b$ & $72.43 b$ & $83.24 b c$ \\
\hline Kopay & $42.49 \mathrm{a}$ & $74.53 b$ & $86.83 \mathrm{ba}$ \\
\hline \multicolumn{4}{|c|}{ Dosis pellet $T$. harzianum (T) } \\
\hline 0 g per tanaman & 39.65 & 72.05 & 83.79 \\
\hline $10 \mathrm{~g}$ per tanaman & 40.38 & 71.89 & 84.58 \\
\hline $15 \mathrm{~g}$ per tanaman & 39.98 & 73.88 & 83.93 \\
\hline $20 \mathrm{~g}$ per tanaman & 40.72 & 75.15 & 87.08 \\
\hline
\end{tabular}

Keterangan: Angka yang diikuti oleh huruf yang berbeda pada kolom yang sama pada masing-masing perlakuan menunjukkan berbeda nyata berdasarkan uji DMRT pada taraf $\alpha=5 \%$ 


\section{Jumlah Cabang Tersier}

Analisis sidik ragam menunjukkan bahwa perlakuan varietas dan dosis T. harzianum tidak berpengaruh terhadap jumlah cabang tanaman cabai. Rata-rata jumlah cabang tertinggi pada umur 20 dan 40 HST ditunjukkan oleh varietas Lado dengan dosis pellet $T$. harzianum $20 \mathrm{~g}$ per tanaman, sedangkan pada umur 60 HST ditunjukkan oleh varietas Bemeri dengan dosis pellet $T$. harzianum $20 \mathrm{~g}$ per tanaman (Gambar 1). Hal ini menunjukkan bahwa faktor varietas dan dosis pellet $T$. harzianum memberikan pengaruh yang relatif sama terhadap pertumbuhan jumlah cabang tanaman cabai.

Jumlah cabang pada tanaman cabai terdiri dari cabang primer, sekunder dan tersier yang sangat mempengaruhi jumlah buah tanaman. Buah pada tanaman cabai banyak tumbuh pada ujung-ujung cabang tersier sehingga semakin banyak percabangan maka peluang peningkatan jumlah buah per tanaman semakin tinggi. Jumlah cabang memberikan pengaruh yang signifikan terhadap bobot buah per tanaman karena peningkatan jumlah cabang dapat meningkatkan jumlah buah yang berpengaruh secara langsung terhadap peningkatan bobot buah per tanaman (Hapsari et al., 2017). Jumlah cabang tanaman berkorelasi positif dengan peningkatan tinggi tanaman karena proses pertambahan tinggi tanaman memperbesar peluang pertumbuhan tunastunas baru pada ruas-ruas batang tanaman seiring dengan peningkatan pembelahan sel-sel meristem apikal dan perpanjangan sel pada bagian tanaman muda (Hermansyah dan Inoriah, 2009).

\section{Lebar Kanopi}

Analisis sidik ragam menunjukkan bahwa faktor varietas berpengaruh sangat nyata terhadap lebar kanopi tanaman cabai pada umur 20, 40, dan 60 HST, namun perlakuan dosis $T$. harzianum berpengaruh tidak nyata terhadap lebar kanopi pada umur 20, 40, dan 60 HST. Hasil uji lanjut faktor varietas (Tabel 3) menunjukkan bahwa varietas Lado memiliki kanopi terlebar yang berbeda nyata dengan varietas Kencana, tetapi tidak berbeda dengan varietas Kopay dan Bemeri. Hal ini menunjukkan bahwa setiap varieras memiliki karakter tumbuh yang berbedabeda sehingga respon yang ditunjukkan pada kondisi lingkungan tumbuh berbeda-beda sesuai dengan poetnsi genetik tanaman.

Muniarti et al. (2013) menyatakan bahwa tajuk tanaman (kanopi) dipengaruhi oleh tinggi, jumlah daun, dan percabangan tanaman cabai karena semakin banyak jumlah daun, dan percabangan tanaman akan berbading lurus dengan lebar tajuk tanaman. Hasil penelitian Rofidah et al. (2018) menunjukkan bahwa tinggi dan diameter batang berkorelasi positif dengan jumlah buah per tanaman. Tinggi dan dimeter batang tanaman merupakan komponen tajuk (kanopi tanaman) sehingga pertambahan tinggi dan diameter batang dapat mempengaruhi luas kanopi tanaman cabai.

Hasil analisis sidik ragam menunjukkan bahwa faktor dosis pellet $T$. harzianum tidak berpengaruh terhadap lebar kanopi tanaman umur 20, 40, dan $60 \mathrm{HST}$. Hal ini terjadi karena lebar kanopi tanaman merupakan salah satu indikasi pertambahan tinggi tanaman dan jumlah cabang yang terbentuk sehingga membentuk kanopi tanaman. Jumlah cabang dan tinggi tanaman yang optimal berbanding lurus dengan peningkatan lebar kanopi tanaman. Hasil analisis sidik ragam menunjukkan bahwa faktor dosis pellet $T$. harziaunm tidak berpengaruh terhadap tinggi tanaman dan jumlah cabang tersier sehingga berkolerasi positif dengan hasil analisis pada lebar kanopi tanaman.

Kondisi lingkungan tumbuh $T$. harzianum sangat menentukan efektivitas dan efisiensi T. harzianum dalam membantu pertumbuhan tanaman cabai. Ketersedian

$\because 20 \mathrm{HST} \quad 40 \mathrm{HST} \backsim 60 \mathrm{HST}$

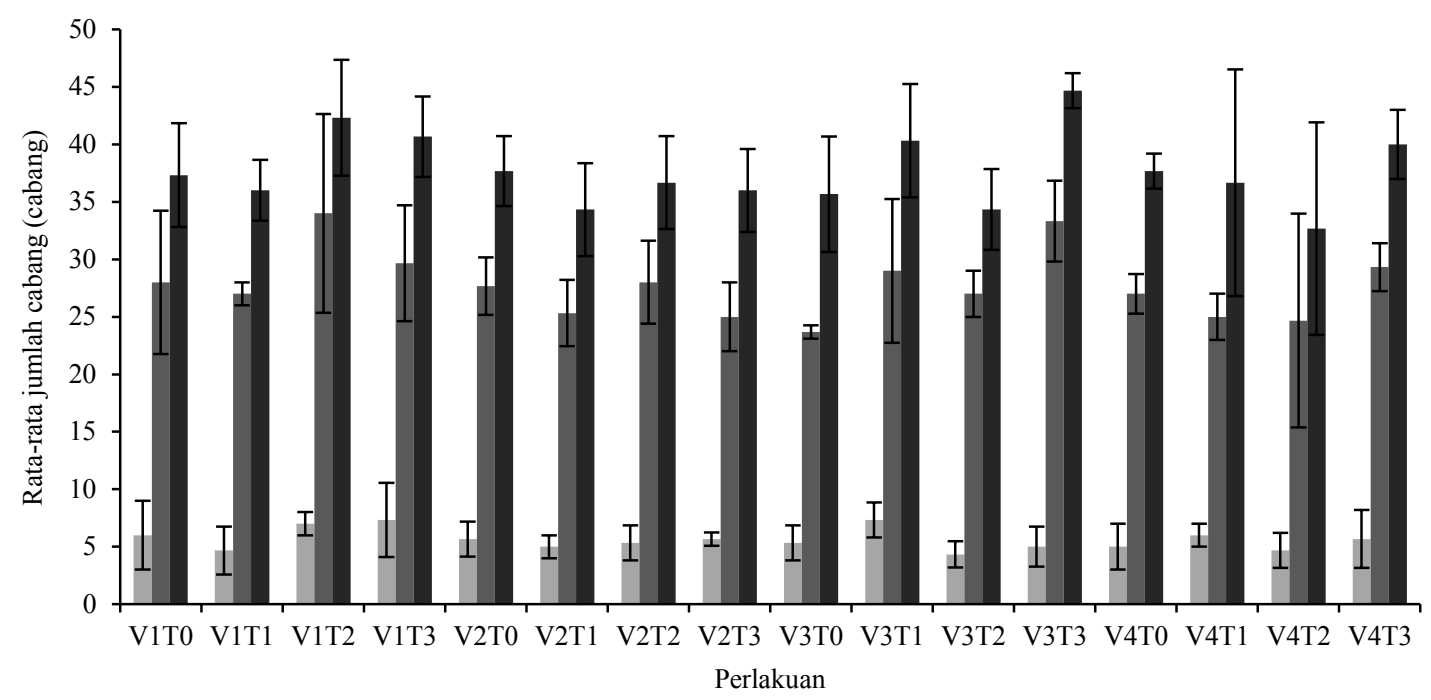

Gambar 1. Rata-rata jumlah cabang tanaman pada umur 20, 40, dan 60 HST dengan aplikasi dosis pellet T. harzianum pada varietas cabai. $\mathrm{V} 1=$ Lado; $\mathrm{V} 2=$ Kencana; V3 = Bemeri; V4 = Kopay; $\mathrm{T} 0=0 \mathrm{~g}$ per tanaman; $\mathrm{T} 1=10 \mathrm{~g}$ per tanaman; $\mathrm{T} 2=15 \mathrm{~g}$ per tanaman; $\mathrm{T} 3=20$ g per tanaman. Bar \pm S.E. 
Fitria et al. / J. Agron. Indonesia 49(1):45-52

Tabel 3. Rata-rata lebar kanopi varietas cabai dengan aplikasi berbagai dosis T. harzianum umur 20, 40, dan 60 HST

\begin{tabular}{|c|c|c|c|}
\hline \multirow{2}{*}{ Perlakuan } & \multicolumn{3}{|c|}{ Lebar kanopi $(\mathrm{cm})$} \\
\hline & $20 \mathrm{HST}$ & $40 \mathrm{HST}$ & $60 \mathrm{HST}$ \\
\hline \multicolumn{4}{|l|}{ Varietas (V) } \\
\hline Lado & $52.35 \mathrm{a}$ & $110.16 \mathrm{a}$ & $132.19 \mathrm{a}$ \\
\hline Kencana & $46.88 b$ & $86.86 b$ & $115.33 b$ \\
\hline Bemeri & $51.43 \mathrm{a}$ & $103.05 \mathrm{a}$ & $126.90 \mathrm{a}$ \\
\hline Kopay & $51.49 \mathrm{a}$ & $104.00 \mathrm{a}$ & $130.16 a$ \\
\hline \multicolumn{4}{|c|}{ Dosis pellet $T$. harzianum (T) } \\
\hline $0 \mathrm{~g}$ per tanaman & 48.89 & 98.64 & 122.87 \\
\hline $10 \mathrm{~g}$ per tanaman & 51.82 & 100.06 & 124.07 \\
\hline $15 \mathrm{~g}$ per tanaman & 51.82 & 103.58 & 127.67 \\
\hline 20 g per tanaman & 51.09 & 101.80 & 129.98 \\
\hline
\end{tabular}

Keterangan: Angka yang diikuti oleh huruf yang berbeda pada kolom yang sama pada masing-masing perlakuan menunjukkan berbeda nyata berdasarkan uji DMRT pada taraf $\alpha=5 \%$

sumber makanan T. harzianum pada media tanaman sangat menentukan efektivitas T. harzianum dalam meningkatkan pertumbuhan tanaman. Aplikasi T. harzianum dilakukan pada media tanam dengan campuran pupuk kandang dan sekam sehingga sumber makanan berasal dari pupuk kandang dan sekam yang membutuhkan waktu yang lama untuk dihancurkan menjadi molekul-molekul organik yang mudah diserap. Menurut Baihaqi et al. (2013), sumber makanan, curah hujan serta kelembaban udara yang kurang cukup mempengaruhi ruang tumbuh untuk pertumbuhan Trichoderma sp., dan juga akan berpengaruh kepada efisiensi aplikasi Trichoderma sp. yang berdampak pada pertanaman.

\section{Panjang Akar, Bobot Segar Akar, dan Bobot Kering Akar}

Hasil uji lanjut (Tabel 4) menunjukkan bahwa varietas Lado memiliki rata-rata akar terpanjang yang berbeda nyata dengan varietas Kopay, tetapi tidak berbeda dengan varietas Bemeri dan Kencana. Perbedaan panjang akar dipengaruhi oleh oleh faktor faktor genetik dan faktor lingkungan tumbuh tanaman cabai. Kusmana et al. (2016) menyatakan bahwa faktor genetik tanaman dan adanya perbedaan susunan genetik pada jenis tanaman yang sama dapat mengakibatkan perbedaan keragaman morfologi tanaman. Hal ini mengakibatkan adanya perbedaan panjang akar tanaman antar varietas cabai.

Pada faktor dosis pellet $T$. harzianum, hasil uji lanjut (Tabel 4) menunjukkan bahwa dosis pellet T. harzianum 20 g per tanaman memiliki akar terpanjang yang berbeda nyata dengan dosis pellet $T$. harzianum lainnya. T. harzianum memproduksi auksin dalam bentuk IAA pada permukaan dan ujung akar tanaman yang dapat menstimulir pemanjangan akar, inisiasi akar sekunder, pembentukan serabut akar dan meningkatkan respon akar pada tanaman sehingga dapat meningkatkan peran akar terhadap penyerapan unsur hara dan air dari tanah (Hopkins dan Huner, 2008). Akar tanaman berperan aktif dalam proses penyerapan unsur hara dan air pada tanaman sehingga panjang dan jumlah akar mempengaruhi jangkauan dan jumlah unsur hara dan air yang dapat diserap tanaman. Aplikasi T. harzianum dapat merangsang pembentukan dan perpanjangan akar tanaman cabai sehingga proses penyerapan unsur hara dan air menjadi lebih optimal. Shoresh dan Harman (2008) menyatakan bahan-bahan metabolit sekunder yang berfungsi untuk meningkatkan pertumbuhan akar tanaman dapat diproduksi oleh T. harzianum sehingga meningkatkan kemampuan tanaman dalam menyerap unsur hara dari dalam tanah.

\section{Bobot Brangkasan Basah dan Brangkasan Kering}

Hasil analisis sidik ragam menunjukkan bahwa varietas berpengaruh sangat nyata terhadap bobot brangkasan basah dan brangkasan kering tanaman, sedangkan dosis $T$. harzianum tidak berpengaruh terhadap bobot brangkasan basah tanaman, tetapi berpengaruh nyata terhadap bobot brangkasan kering. Hasil uji lanjut (Tabel 5) menunjukkan varietas Lado memiliki bobot brangkasan basah dan brangkasan kering tertinggi yang berbeda nyata dengan varietas Kencana dan Kopay tetapi tidak berbeda dengan varietas Bemeri. Variabel tinggi tanaman, jumlah cabang dan lebar tajuk sangat mempengaruhi bobot brangkasan basah dan kering tanaman. Varietas Lado memiliki rata-rata tinggi, jumlah cabang dan lebar kanopi tertinggi sehingga secara langsung berkorelasi positif dengan bobot brangkasan basah dan kering tanaman. Hasil penelitian Sepwanti et al. (2016) menunjukkan bahwa perlakuan varietas tanaman cabai berpengaruh nyata terhadap tinggi dan diameter batanag tanaman dengan perlakuan varietas F-1 Paramas 201 memiliki hasil yang terbaik.

Berdasarkan hasil uji lanjut (Tabel 5) menunjukkan bahwa rata-rata bobot brangkasan basah dan bobot 
Tabel 4. Rata-rata panjang akar, bobot segar dan bobot kering akar varietas cabai dengan aplikasi berbagai dosis $T$. harzianum

\begin{tabular}{lccc}
\hline Perlakuan & Panjang akar $(\mathrm{cm})$ & Bobot segar akar $(\mathrm{g})$ & Bobot kering akar $(\mathrm{g})$ \\
\hline Varietas $(\mathrm{V})$ & & & \\
Lado & $20.31 \mathrm{a}$ & 21.81 & 16.59 \\
Kencana & $19.36 \mathrm{ab}$ & 18.39 & 16.46 \\
Bemeri & $19.91 \mathrm{a}$ & 22.22 & 18.23 \\
Kopay & $18.12 \mathrm{~b}$ & 19.70 & 15.33 \\
Dosis pellet T. harzianum (T) & & & \\
0 g per tanaman & $18.86 \mathrm{~b}$ & 20.39 & 16.27 \\
10 g per tanaman & $18.67 \mathrm{~b}$ & 19.31 & 14.98 \\
15 g per tanaman & $19.22 \mathrm{~b}$ & 19.70 & 18.16 \\
20 g per tanaman & $20.94 \mathrm{a}$ & 22.72 & 17.19 \\
\hline
\end{tabular}

Keterangan: Angka yang diikuti oleh huruf yang berbeda pada kolom yang sama pada masing-masing perlakuan menunjukkan berbeda nyata berdasarkan uji DMRT pada taraf $\alpha=5 \%$

brangkasan kering tanaman cabai mengalami peningkatan secara signifikan sejalan dengan bertambahnya dosis pellet T. harzianum. Dosis pellet T. harzianum $20 \mathrm{~g}$ per tanaman menunjukkan nilai brangkasan kering tanaman lebih tinggi yang berbeda nyata dengan perlakuan tanpa $T$. harzianum tetapi dan tidak berbeda dengan dosis T. harzianum 10 dan 15 g per tanaman. Bobot kering tanaman merupakan gambaran dari penimbunan atau absorbsi bersih asimilasi fotosintesis yang diperoleh selama pertumbuhan dan perkembangan tanaman. Peningkatan bobot segar dan pertumbuhan tanaman dapat memberikan pengaruh nyata terhadap bobot kering tanaman.

Tabel 5. Rata-rata bobot brangkasan basah dan kering varietas cabai dengan aplikasi berbagai dosis $T$. harzianum

\begin{tabular}{lcc}
\hline Perlakuan & $\begin{array}{c}\text { Bobot } \\
\text { brangkasan } \\
\text { basah }(\mathrm{g})\end{array}$ & $\begin{array}{c}\text { Bobot } \\
\text { brangkasan } \\
\text { kering }(\mathrm{g})\end{array}$ \\
\hline Varietas $(\mathrm{V})$ & & \\
$\quad$ Lado & $331.92 \mathrm{a}$ & $128.30 \mathrm{a}$ \\
Kencana & $261.67 \mathrm{~b}$ & $114.02 \mathrm{~b}$ \\
Bemeri & $321.28 \mathrm{a}$ & $122.33 \mathrm{ab}$ \\
Kopay & $256.06 \mathrm{~b}$ & $113.89 \mathrm{~b}$ \\
Dosis pellet T. harzianum $(\mathrm{T})$ & & \\
0 g per tanaman & 276.75 & $112.09 \mathrm{~b}$ \\
10 g per tanaman & 281.82 & $118.53 \mathrm{ab}$ \\
15 g per tanaman & 303.78 & $120.04 \mathrm{ab}$ \\
20 g per tanaman & 308.58 & $127.88 \mathrm{a}$ \\
\hline
\end{tabular}

Keterangan: Angka yang diikuti oleh huruf yang berbeda pada kolom yang sama pada masing-masing perlakuan menunjukkan berbeda nyata berdasarkan uji DMRT pada taraf $\alpha=5 \%$
T. harzianum menghasilkan Indole Acetic Acid (IAA) yang dapat membantu pertumbuhan dan perkembangan tanaman sehingga berpengaruh positif terhadap bobot brangkasan tanaman cabai. Penelitian Yadav et al. (2011) menunjukkan bahwa cendawan Aspergillus niger menghasilkan IAA sebesar ( $85 \mathrm{ug} \mathrm{mL}^{-1}$ ) dan T. harzianum (68 ug $\mathrm{mL}^{-1}$ ) dan Penicillium citrinum (52 ug $\mathrm{mL}^{-1}$ ) pada 3 hari inkubasi dengan suhu $30{ }^{\circ} \mathrm{C}$. IAA memiliki peran penting dalam mendukung pertumbuhan tanaman karena mampu merangsang pertumbuhan akar tanaman sehingga tanaman mampu menyerap hara dan air lebih optimal. Aplikasi IAA dengan konsentrasi 200 ppm dapat meningkatkan tinggi tanaman, jumlah cabang sekunder dan luas daun tanaman sehingga dapat bobot brangkasan basah dan kering tanaman cabai menjadi lebih tinggi (Sing et al., 2012). Sejalan dengan itu, penelitian Kurniawan et al. (2016) menunjukkan bahwa aplikasi (IAA) konsentrasi 100 ppm memberikan hasil terbaik terhadap tinggi dan jumlah daun tanaman cabai dibandingkan dengan konsentrasi yang lebih tinggi dan rendah karena kekurangan dan kelebihan IAA dapat menghambat pertumbuhan tanaman.

\section{Bobot Buah per Tanaman}

Hasil analisis sidik ragam menunjukkan bahwa faktor varietas dan dosis pellet $T$. harzianum tidak berpengaruh terhadap bobot buah per tanaman cabai. Rata-rata bobot buah per tanaman tertinggi ditunjukkan oleh varietas Lado dengan dosis pellet $T$. harzianum 20 g per tanaman sedangkan terendah pada varietas Kencana dengan dosis pellet $T$. harzianum $0 \mathrm{~g}$ per tanaman (Gambar 2). Hal ini terjadi karena varietas memiliki kemampuan tumbuh yang berbeda-beda sesuai dengan kondisi lingkungan dan ketersedian unsur hara pada media tanam. Selain itu, T. harzianum merupakan agens hayati yang mampu memproduksi IAA yang berperan dalam mendukung pertumbuhan vegetatif, tetapi tidak dapat berperan secara langsung terhadap komponen produksi 


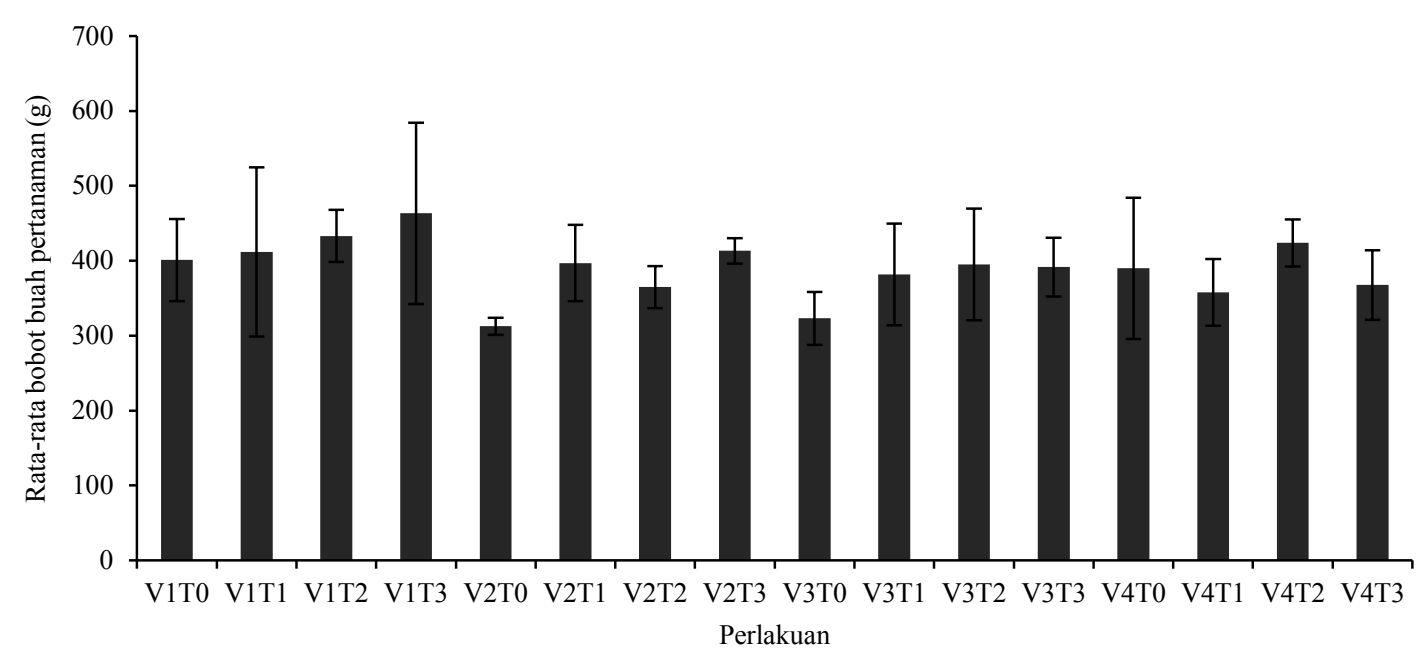

Gambar 2. Rata-rata bobot buah per tanaman dengan aplikasi dosis pellet $T$. harzianum pada varietas cabai. V1 = Lado; V2 = Kencana; $\mathrm{V} 3=$ Bemeri; $\mathrm{V} 4=$ Kopay; $\mathrm{T} 0=0 \mathrm{~g}$ per tanaman; $\mathrm{T} 1=10 \mathrm{~g}$ per tanaman; $\mathrm{T} 2=15 \mathrm{~g}$ per tanaman; $\mathrm{T} 3=20 \mathrm{~g}$ per tanaman. $\operatorname{Bar} \pm$ S.E.

tanaman. Aplikasi jamur T. harzianum tidak dapat secara langsung memberikan pengaruh terhadap variabel hasil tanaman kentang karena memiliki peran utama sebagai pengendali penyakit dan mendegradasi bahan organik, bukan sebagai sumber nutrisi bagi tanaman (Hermawan et al., 2013). Hal ini menunjukkan bahwa T. harzianum memiliki peran penting dalam merangsang pembentukan jaringan pada akar tanaman sehingga mempermudah penyerapan air dan hara, tetapi peningkatan pertumbuhan dan produktivitas tanaman dipengaruhi oleh ketersedian hara pada media tanam.

\section{KESIMPULAN}

Faktor tunggal dosis pellet $T$. harzianum dan varietas tanaman berpengaruh nyata terhadap sebagian variabel pertumbuhan tanaman, tetapi tidak berpengaruh terhadap bobot buah per tanaman. Perlakuan varietas Lado memberikan hasil terbaik pada variabel tinggi tanaman umur 20, 40, dan 60 HST, lebar kanopi umur 20, 40, dan 60 HST, panjang akar, bobot brangkasan basah dan brangkasan kering tanaman cabai. Perlakuan dosis pellet $T$. harzianum 20 g per tanaman memberikan hasil terbaik pada variabel panjang akar dan bobot brangkasan kering tanaman.

\section{DAFTAR PUSTAKA}

Baihaqi, A., M. Nawawi, dan A.L. Abadi. 2013. Teknik aplikasi Trichoderma sp. terhadap pertumbuhan dan hasil tanaman kentang (Solanum tuberosum L). J. Produksi Tanaman 1:30-39.

Hapsari, R., D. Indradewa, E. Ambarwati. 2017. Pengaruh pengurangan jumlah cabang dan jumlah buah terhadap pertumbuhan dan hasil tomat (Solanum lycopersicum L.). J. Vegetalika 6:37-49.
Hardianti, A.R., Y.S. Rahayu, M.T. Asri. 2014. Efektivitas waktu pemberian trichoderma harzianum dalam mengatasi serangan layu fusarium pada tanaman tomat varietas Ratna. J. Lentera Bio. 3:21-25.

Hermansyah, Y., E. Inoriah. 2009. Penggunaan pupuk daun dan manipulasi jumlah cabang yang ditinggalkan pada panen kedua tanaman nilam. Akta Agrosia 12: 194-203.

Hermawan, R., M.D. Maghfoer, T. Wardiati. 2013. Aplikasi Trichoderma harzianum terhadap hasil tiga varietas kentang di dataran medium. J. Produksi tanaman 1:464-470.

Hermosa, R., A.V.I. Chet, E. Monte. 2012. Plant beneficial effects of Trichoderma and of its genes. J. Microbiology 158:17-25.

Hermosa, R., M.B. Rubio, R.E. Cardoza, C. Nicolas, E. Monte, S. Guteirrez. 2013. The contribution of Trichoderma to balancing the cost of glant growth and defense. J. Microbiology 16:69-80.

Hopkins, W.G., N. P. A. Huner. 2008. Introduction to plant physiology. The University of Western Ontario, Ontorio, CA.

Kurniawan, F., Koesriharti, M. Nawawi. 2016. Respon dua varietas cabai merah (Capsicum annum L.) terhadap pemberian IAA (Indole Acetic Acid). J. Produksi Tanaman 4:660-666.

Kusmana, Y. Kusandriani, R. Kirana, Liferdi. 2016. Keragaan tiga galur lanjut cabai merah pada ekosistem dataran tinggi Lembang, Jawa Barat. J. Horticulture 26:133142. 
Marliah, A., M. Nasution, Armin. 2011. Pertumbuhan dan hasil beberapa varietas cabai merah pada media tumbuh yang berbeda. J. Floratek 6:84-91.

Murniati, N.S., Setyono, A.A. Sjarif. 2013. Analisis korelasi dan sidik lintas peubah pertumbuhan terhadap produksi cabai merah (Capsicum annum L.). J. Pertanian 3:111-122.

Rofidah, N.M., I. Yulianah, Respatijarti. 2018. Korelasi antara komponen hasil dengan hasil pada populasi F6 tanaman cabai merah besar (Capsicum annum L.). J. Produksi Tanaman 6:230-235.

Rohmawati, I, D. Hastuti, Purwati. 2018. Pengaruh pemberian berbagai konsentrasi gibberellic acid dan jenis varietas terhadap pertumbuhan dan hasil tanaman cabai rawit (Capsicum frutescens L.). J. Agroekotek. 10:19-31.

Sepwanti, C., M. Rahmawati, E. Kesumawati. 2016. Pengaruh varietas dan dosis kompos yang diperkaya Trichoderma harzianum terhadap pertumbuhan dan hasil tanaman cabai merah (Capsicum annuum L.). J. Kawista 1:68-74.

Shoresh, M., G.E. Harman. 2008. The relationship between increased growth and resistance induced in plants by root colonizing microbes. Plant Signaling Behav. 3:737-739.
Singh, R.N., S.L. Pal, D.K. Rana, S.S. Rawat, M.S. Gusain. 2012. Effect of bio-regulators on growth and yield parameters of capsicum cultivars under controlled condition. J. HortFlora Res. Spectrum 1:50-54.

Sriwati, R., T. Chamzurni, L. Kemalasari. 2014. Kemampuan bertahan hidup Trichoderma harzianum dan Trichoderma virens setelah ditumbuhkan bersama dengan jamur patogen tular tanah secara in vitro. J. Floratek 9:14-21.

Yadav, J., J.P. Verma, K.N. Tiwari. 2011. Plant growth promoting activities of fungi and their effect on chickpea plant growth. Asian J. Biol. Sci. 4:291299.

Zikriah. 2016. Potensi daun katuk dan lamtoro sebagai nutrisi cendawan Trichoderma $s p$. pada pelet media tumbuh dalam menekan pertumbuhan patogen tular tanah. Skripsi. Universitas Syiah Kuala. Banda Aceh, ID.

Zuhry, E., Deviona, M. Syukur, S. Sujiprihati, Telphy. 2012. Uji daya hasil beberapa genotipe cabai (Capsicum annuum L.) toleran pada lahan gambut. J. Agroteknologi Tropika 1:1-7. 